\title{
Sor Juana and the Painters - A Neo-baroque Perspective
}

\author{
Rosario FARAUDO \\ Universidad Nacional Autónoma de México
}

Sor Juana Ines de la Cruz (1651-1695) the famous Mexican Baroque poet, belonged to an eccentric world. A world that had been decentered by Kepler's laws, shifting from the perfect circle to the ellipse, a discovery that, in Severo Sarduy's opinion, brought about a shift from the Classical to the Baroque "lo barroco queda definido como el reflejo de un mundo que a partir de Kepler, se sabe descentrado" (Celorio, 2001: 82). In addition, society in colonial New Spain did not reproduce the one in Spain. At best, it reflected a distorted image of the "mother country" which at the time was quickly sliding into decadence. Sor Juana herself was a decentered person in many ways: although a creole, there are doubts as to the identity of her father, who apparently was not married to her mother, she had no fortune, and in addition, she was a nun, therefore "dead" to the world. All this would be enough to set her on the margins of society, but a woman who read and wrote in those days was extremely unusual, particularly in the context of the Counter-Reformation.

Although her personality is quite enigmatic, and many aspects of her life remain obscure, there are signs in her poetry that reveal a spirit ahead of her time.

I do not intend to analyze her work in this brief paper, since this has been done exhaustively by scholars like José Pascual Buxó and poets like Octavio Paz and Ramón Xirau. My interest at present is to observe how renewed interest in the Baroque has transcended the field of literature, and Sor Juana is once more attracting the attention of artists who recreate and update the Baroque with contemporary techniques and attitudes. The recovery of the Baroque in the Spanish New World and the way in which Neobaroque writers have reinterpreted their Baroque legacy, has extended to the visual arts as well. I intend here to examine an interesting example of this tendency, which is by no means isolated.

The poetry of Sor Juana was greatly admired in her time, and she enjoyed a number of privileges in the convent due in part to her close connections with the Viceregal court. She even had her portrait painted, probably by Juan de Miranda, although there is considerable doubt as to the dates and circumstances (Paz, 1985: 359). This is part of the obscurity that surrounds Sor Juana's life and which, in true Baroque fashion, extends to most of her work. The best known portraits of the poet are the one by Miranda and especially one by Miguel Cabrera (fig. 1), done in 1750 (obviously a copy, since Sor 


\section{$64 \square$ SOR JUANA AND THE PAINTERS}

Juana died in 1695). Octavio Paz suggests these portraits parallel Sor Juana's poems, in their ambiguous image of seduction and disenchantment $(1985,358)$.

The portrait by Miguel Cabrera, now in the Chapultepec History Museum, shows a large image of Sor Juana in the foreground. She is sitting at a desk, with one hand on an open book and touching her rosary with the other. This attitude denotes the intention of the painter to reveal the subject's interior identity; a commitment to learning as well as to religion. In tracing the development of the art of portrait, Irene Artigas mentions the importance the XVII century attached to reflecting the "interiority" of the model, something that can be observed in Rembrandt's portraits, for example (2004, 128). Another tradition of the period required the inclusion of objects that would help to define the identity of the subject and enhance its dignity (Artigas,2004:126). Thus in this portrait, the space behind the poet is completely covered with books and decorated with rich scarlet hangings that match the table cover. There are inscriptions at the bottom identifying the subject and the artist, leaving no empty spaces - and revealing the Baroque horror of the void. Even the names of the books in the background can be read, which suggests that Sor Juana is posing in her cell-library. Cabrera added a set of quill pens on the table to complete the personification of the poet. Whether intentionally or not, the painter created a context that bears witness to the poet's thirst for universal knowledge. Learning implied a transgression for her. She confessed she read every book she could, disregarding the risk of punishment (Paz, 1985: 122). This thirst for knowledge in Sor Juana — as in her contemporary Carlos de Sigúenza y Góngora - implies a rebellion, to which Lezama Lima attributes a political meaning (Irlemar Chiampi, 2000, 23).

Accordingly, this contemporary picture of Sor Juana, by Mexican artist Arcadi Artis (fig. 2) follows the rebellious trend and contains several traits related to the Latin American Neobaroque. To begin with, the artist used an unconventional medium (CAD-computer architectonic design), not normally associated with portrait painting. The picture is parodic, since its obvious relationship to the Cabrera painting constitutes a form of inter-art discourse (Hutcheon: 2).

Severo Sarduy states that parody is the privileged instrument of Neobaroque strategies of displacement; it recuperates previous models and subverts them in one way or another (Parkinson, 2006: 294). The parody in this picture, however, is not aimed at subverting a literary text but a Baroque painting.

Viewers familiar with the portrait by Miguel Cabrera will at once recognize the parodic dimension in the small likeness of the nun, seated at a "table", in exactly the same position as she appears in the Cabrera painting. Since the encoding agent demands the decoder's interpretation to complete the parodic operation (Hutcheon, 1985: 53), the viewer's recognition of the original painting will intensify the effect, the Neobaroque game. In Gonzalo Celorio's opinion, "la parodia implica un doble discurso, una doble textualidad: un discurso referencial previo, conocido y reconocible, que es deformado, alterado, escarnecido, llevado a sus extremos por el discurso del barroco" (2001: 101). These conditions embrace the visual arts as well, since they are another form of dis- 
course. This imitation of a Baroque painting, is an imitation in the sense of emulation, which produces a new text - a text that will surely be recognized by all "de simultánea sujeción y apartamiento del texto modélico” (Pascual Buxó, 2002: 98).

In the contemporary composition — since we cannot call it a painting - proportion has been completely distorted; the face of the nun has become a mask, and details have been eliminated, only the outlines of the central figure remain, but the luminous center stands out. The table seems to be floating next to the nun with vertical orange lines crossing its center. Although the size of the subject has been reduced, and perspective distorted, the nun continues to be the focal point through an effect of chiaroscuro. This effect matches the technique Sor Juana frequently used in her poetry, where she contrasted light and darkness, especially in her famous poem Primer Sueño, a poem, written after the model of Góngora's Soledades.

The image of the poet is enclosed inside an intricate geometrical design in different tones of black and orange that creates an illusion of depth and enhances the chiaroscuro. This pattern offers a great opportunity for semantic diffusion, since it opens the door to a number of interpretations. The linear design retains the Baroque traits of exuberance, artifice and contrast but with a contemporary twist. The horizontal lines at the back could take the place of the books and hangings in the original painting, but they have surpassed the function of background decoration. This "cage-like" pattern has grown in size, perhaps to symbolize the walls of the cell, the convent —or prison — that Juana Inés never left. The top of the enclosure changes direction at an angle, like some kind of a lid or cover opening on a hinge. The dark "wall" also stands for the repression the Catholic hierarchy exercised on the nun later in her life, preventing her from reading secular texts and writing any more. Nevertheless, the luminous orange lines across the center draw a vertical axis that elongates the design, producing an upward movement that reaches beyond the top of the wall.

This may be read in terms of Sor Juana's spirit soaring above the limits her world imposed on her, and obtaining liberty through her art. As Octavio Paz beautifully puts it: "La clausura se transforma en un universo de signos y el claustro se abre hacia un espacio sin fronteras..." $(1985,129)$. There are several aspects of her poetry that support these interpretations. One of these is found in her identification with Phaeton/ Icarus, the over-reachers, which she related to her failed ambitions for intellectual and poetical development. Another aspect of Sor Juana's poetry that this design evokes is her use of the pictorial technique of contrast between dark and light applied to the nocturnal landscape.

The subject's name does not appear in this picture, but the insertion of the first quatrain of one of her sonnets in the composition creates an ekphrasis, which multiplies the possible readings. This is one of her philosophical poems that refers to the treachery of illusion. Although it does not contain a reference to a specific portrait there are indications that link it to one of Sor Juana's portraits.

The poet is looking at her likeness in the picture and actually writing herself into the poem (Soneto 145, 1996: 134): 
Este que ves, engaño colorido, Que del arte ostentando los primores, Con falsos silogismos de colores Es cauteloso engaño del sentido;

The rest of the sonnet continues dealing with themes common to the writing of her age:

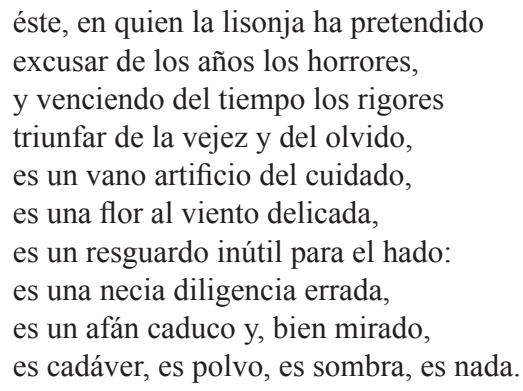

The deceit she mentions may now refer to portrait painting in general, to the original portrait of the poet or/and to this new picture. Actually the three interpretations are activated and could be multiplied by reference to the whole sonnet. The poem is in itself ekphrastic since it refers to a plastic object, but it has now become part of it and thus has extended its textual limits.

If we take Ekphrasis as "the verbal representation of a visual object", as in James Heffernan's definition (Pimentel, 2003: 206), we should recall that although this particular poem is not descriptive, according to the model proposed by Valerie Robillard to classify the different types of ekphrastic relationships (Artigas, 2004: 59), it can be considered representative since it presents explicitly an existing artistic object. Exploring the limits of ekphrasis Luz Aurora Pimentel explains that where the presence of a verbal text is found in a visual one, there is a relationship Peter Wagner has called intermediality (2003: 206), an operation that relates at least two forms of representation. When the visual image and the verbal text cannot be separated, we are in the presence of an iconotext. This applies especially to Artis' picture, since the sonnet has been inserted into the plastic object. This double texture modifies our perception of the plastic object in accordance to the values established by the verbal text (2003: 206).

The poetic voice is addressing the viewers/readers, orienting their reading toward the artificiality of art, the contrast between reality and appearances, thus stressing artifice, another defining feature of the Baroque. The artificiality in Artis' picture confirms the poet's warning that one is confronting deception. Through the insertion of the verbal text in the composition the verbal has become visual. The limits between the two arts are erased and a dialogue is established between them. The contemporary picture acquires the polyphonic character of every Baroque code, literary or not. It becomes 
"Espacio del dialoguismo, de la polifonía, de la carnavalización, de la parodia y la intertextualidad [...] la mezcla de géneros, la intrusión de un tipo de discurso en otro..." (Severo Sarduy, 1972: 175).

Disregarding the interpretation one may give to this type of art, my proposal is that it reveals more about the subject than the original. There is a process of translation to Neobaroque language that is not a nostalgic evocation but a vigorous recuperation. To borrow a metaphor from Margaret Sayers Peden (1989: 14 ), "Sor Juana's sonnets are baroque edificies in miniature. To translate them the artisan peels away the ornamental gold leaf..." In this case, what the artist has done is to substitute the gold leaf by a live contemporary structure that reinterprets and recuperates the essence of the subject.

Lois Parkinson has traced the $20^{\text {th }}$ Century recovery of the Baroque in Latin American art and the way the legacy of New World Baroque has been reinterpreted by Latin American artists (2006: 287). The question this raises is why is the Baroque so deeply rooted in Latin America as to provoke this "renaissance"?

There is of course no simple answer, but it is an issue that is worth considering. Observing the hybridity in this picture may lead us to reflect on what Alejo Carpentier once said; "Nuestro arte siempre fue barroco... arte nuestro, nacido de árboles, de leños, de retablos y altares, de talles decadentes y retratos caligráficos y hasta neoclasicismos tardíos" (in Chiampi, 2000: 25). Carpentier synthesizes the origin of New World Baroque as a combination of geography and social circumstances brought about by Spanish colonization. At least in Mexico, one may find a number of reasons in our popular culture to justify Carpentier's statements.

The Spanish Baroque of the Counter Reformation was inserted in a geographical context that was (and is) in itself exuberant and contrasting. In Mexico, the Catholic efforts to convert the natives were undertaken first by the Dominican and Franciscan orders and later by the Jesuits. These orders followed the injunctions of the Council of Trent (1545-1547), encouraging the cultivation of piety through visual images, in contrast to the distrust of images brought about by the Protestant Reformation. The art of the natives contained a number of the features associated with the Baroque, as one can still observe in the elaborate designs of the Huicholes, for example. The Catholic clergy used the labor of the natives to build their churches, but to facilitate their conversion allowed them the free flight of their imagination in the decoration. The representation of religious dogma in a tangible way was essential to the new Christians, who produced their own free interpretations, not always very orthodox. Many instances remain where this may be seen nowadays, such as Tlacochahuaya in Oaxaca and Tonantzintla in Puebla. These native interpretations produced a syncretism that has remained alive up to the present, not only in art but in religious rituals as well. The apparition of Our Lady of Guadalupe on a hill where the Indian deity Tonantzin was worshipped represents the most pervasive example of this syncretism. "The miracle of Tepeyac", as the apparitions have been called, became a sort of foundational myth of the Mexican nation, respected to this day. The image of the dark virgin is traditionally depicted in the foreground with small narrative insets at the corners, repre- 
senting the traditional epiphanies. Religious syncretism extends to the celebration of religious feasts with Catholic ceremonies alongside ancient Indian ritual dancing in front and sometimes inside the churches.

We should keep in mind that the symbiosis between Indian and Spanish that we call "mestizaje", is the essence of Mexican identity. This leads us once more to Carpentier, and his belief that "toda simbiosis, todo mestizaje engendra un barroquismo" and that Latin America is in fact " tierra de elección del barroco" (in Chiampi, 2000: 27).

To conclude I would like to point out that our eccentric History and our relationship to the Western centers of power and tradition, have placed us, like Sor Juana in a decentered world. To fully understand contemporary Mexican culture we must keep in mind that we are located between the classical Baroque, the artistry of the native and the modernity of the Neobaroque.

\section{Work cited}

Artigas, Irene. 2004. Galerías de palabras. La variedad de la ecfrasis. México. (Unpublished Dissertation.)

CELORIO, Gonzalo. 2001. "Del barroco al neobarroco". Ensayo de contraconquista. México: Tusquets.

CHIAMPI, Irlemar. 2000. Barroco y modernidad. México: FCE.

CRUZ, Juana Inés de la, sor. 1996. Obras completas. México: Porrúa.

HutcheOn, Linda, 1985. A Theory of Parody. New York: Methuen.

PASCUAL BuXÓ, José. “Sor Juana y Luis de Góngora. El Sueño de sor Juana: reflexión y espectáculo". Actas del Congreso de la Asociación Internacional Siglo de Oro, Burgos-La Rioja, 15-19 de julio de 2002, Iberoamericana Vervuert.

PARKInSON ZAMORA, Lois. 2006. The Inordinate Eye, Chicago: University of Chicago Press.

1998. "Quetzalcoatl's Mirror". In Image and Memory. Austin: University of Texas Press.

PAZ, Octavio. 1985. Sor Juana Inés de la Cruz o las trampas de la fe. México: FCE.

Pimentel, Luz Aurora. 2003. "Écfrasis y lecturas iconotextuales". Poligrafias. México: UNAM, FFL.

SARDUY, Severo. 1972. "El barroco y el neo-barroco". América en su literatura. Ed. César Fernández Moreno. México: Siglo XXI. Pp. 167-184.

. 1974. "Cosmología barroca. Kepler". Barroco. Buenos Aires: Sudamericana.

SAYERS PEDEN, Margaret. 1989. The Craft of Translation. Ed. John BiguenET. Chicago: University of Chicago Press. 
ROSARIO FARAUDO $\square 69$

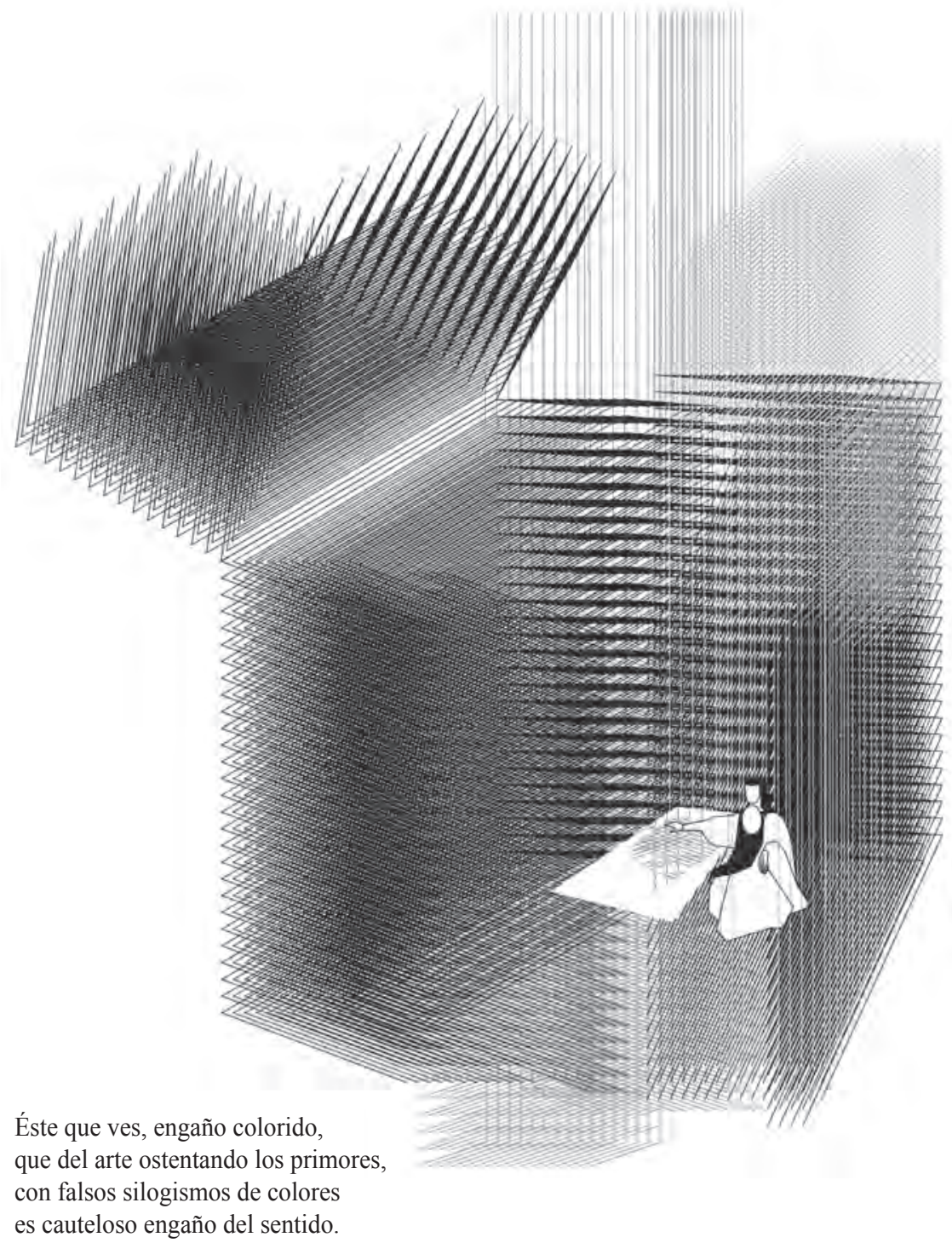

Fragmento del soneto 145 
$70 \square$ SOR JUANA AND THE PAINTERS

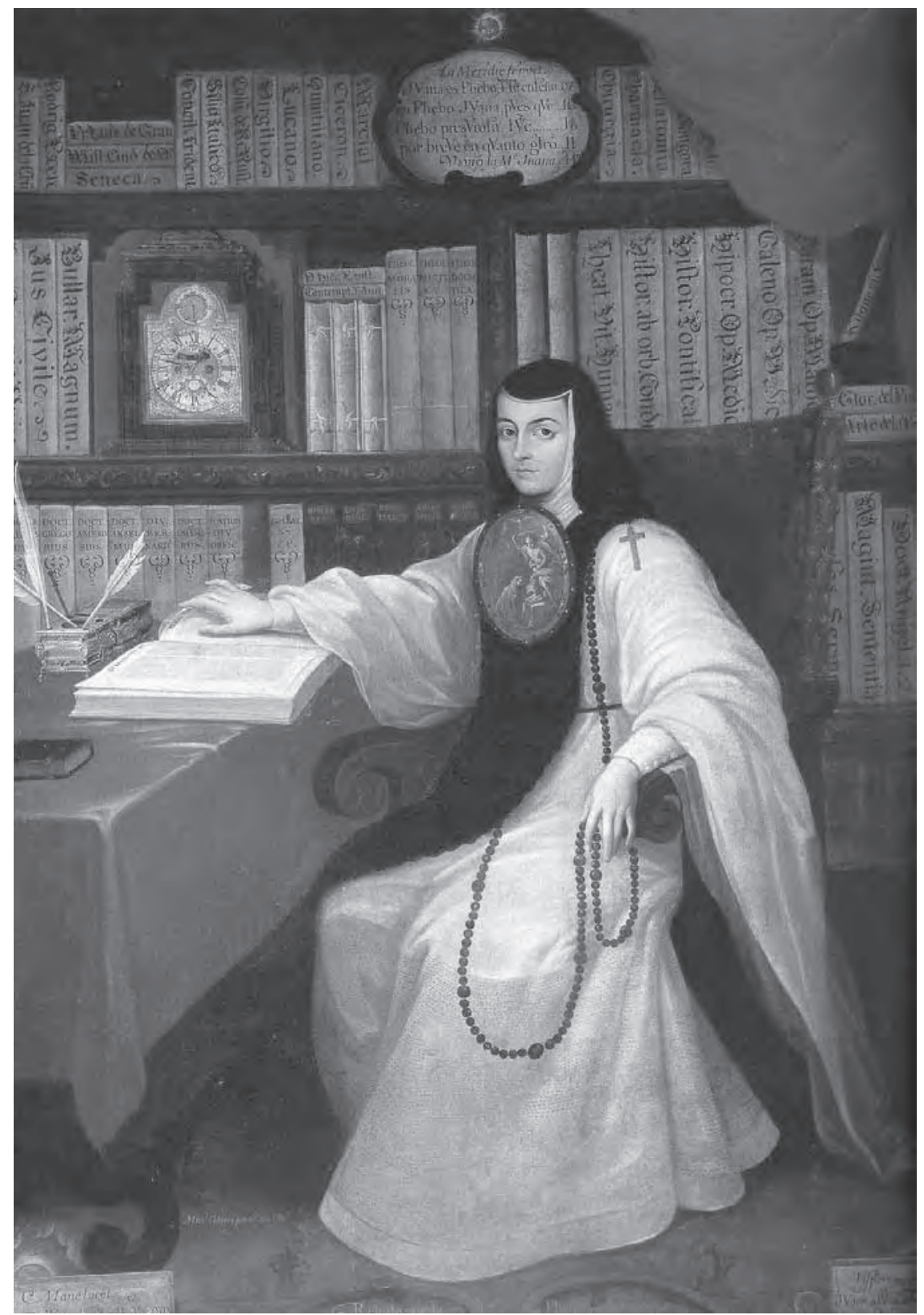

